\title{
Determination of yield and nutrient quality of herbage in Giron Masa grazing reserve, Kebbi State
}

\author{
Birnin-Yauri, H.B. ${ }^{1}$ and S. Umar ${ }^{2}$ \\ I'Division of Sciences and Vocational Education, College of Basic and Advanced Studies, Yelwa Yauri) \\ ${ }^{2}$ (Department of Agricultural Economics and Extension, Kebbi State University of Science and Technology,
} Aliero)

\begin{abstract}
The study determined the crude protein content of herbage collected from Giron Masa grazing reserve, Kebbi State Nigeria. The herbage samples were collected by using $1.0 \mathrm{~m}^{2}$ wooden frame (quadrant). Fresh weight of three most occurring species and remaining other species was taken by the use of spring balance for dry matter determination. Analysis of the data using SAS (1988) package indicated that LDS produces the highest DM and ERS was the least. DM yield on the other hand was highest in EDS and lowest in LRS. From the chemical analysis, highest values of $13.3 \%$ and least value of $5.6 \% \mathrm{CP}$ was obtained in ERS and LDS respectively. The CF content was higher during the LDS (32.4\%) and least in ERS (25.8\%). Other parameters as ash, EE, Ca and $P$ content were also determined. The results of the study indicated a significant effect of season on nutrient content of range herbage. The nutrient contents of the herbage fall within the range considered normal for semi-arid environment. The significant seasonal effect on the quality of the feeds could also be considered normal for plants growing in the semi-arid environment. The dry matter yield data, herbaceous and ligneous species composition and nutrient quality obtained in the present study could be considered fair. This could hold optimum number of livestock with their nutritional requirements, especially during the growing season.
\end{abstract}

Keywords; grazing reserve, herbaceous, ligneous, nutrient, species, yield,

\author{
Abbreviation \\ - ERS- Early rainy season \\ - LRS- Late rainy season \\ - EDS- Early dry season \\ - LDS- Late dry season \\ - $\quad$ CF- Crude fiber \\ - CP-Crude protein \\ - DM- Dry matter \\ - $\quad$ EE- Ether extract
}

\section{Introduction}

The semi-arid rangelands of Africa are characterized by great spatial, intra-seasonal and inter annual variability in primary production and the composition and quality of species. These variations are caused by low and erratic rainfall, heterogeneous rainfall distribution, and high spatial variability of topography and soil physical and chemical properties [1]. Poor nutritive values of forages in the tropics have been acknowledged as an important factor contributing to underdevelopment of ruminant animals [2].

Luxuriant growth of forage does not always indicate its capability to supply adequately the nutritional demands of animals. In much of the tropics annual and seasonal variation in forage availability and quality impose a 'stop-go' growth pattern characterized by alternative gains and losses in animal body weight [3]. At the beginning of the dry season, protein content of 10 to $20 \%$ and digestible dry matter contents of 600 to $700 \mathrm{~g}$ $\mathrm{kg}-1 \mathrm{DM}$ were reported for the herbaceous vegetation of sahelian pastures [4].

Although protein content and digestibility decreases with plant age, the nutritive value of the natural vegetation is generally higher at low biomass production levels as compared to high production levels; at a biomass production of less than 0.1 tone $\mathrm{DM} \mathrm{ha}{ }^{-1}$ grasses contain on average $12.5 \%$ crude protein at the end of the rainy season whereas they contain only $3.1 \% \mathrm{CP}$ when production is about 1.5 to 2.0 ton $\mathrm{DM} \mathrm{ha}^{-1}$ [4]. With a range of 3 to $6 \mathrm{~g} \mathrm{~N} \mathrm{~kg}^{-1} \mathrm{DM}$ in dry annual grasses and from 5 to $8 \mathrm{~g} \mathrm{~N} \mathrm{~kg}^{-1} \mathrm{DM}$ in dry perennials [5]. Younger forage tend to have low dry matter with high nutritive value, while advancing maturity results in increase in dry matter with decreasing nutritive value [3]. 
In many parts of the tropics under natural fertility conditions, and up to about 2 months growth after the onset of rains, the crude protein content in forage grasses is well above $7 \%$. With uninterrupted growth, due to high heat intensity, the grasses rapidly become mature and crude protein content drops drastically, reaching values of 4-6\% after 3-5 months. During dry months, crude protein content often drops below 4\% and in later part of the dry season, values of 1-2\% have been recorded [3]. Crude protein contents of browse plants show much higher values than those of grasses. They vary from $6.1 \%$ in Gardenia erubescens to $37.8 \%$ in Albizzia ferruginia. Crude protein contents of Acacias which forms the most important browse in the Sudan zone, range from 11.8 to $22.4 \%$ [6]. [6] Conducted a research at Shika reported mean crude protein contents of 15.38 and $14.00 \%$ in 21 legumes and 31 non-legumes respectively. These were obtained from browse taken from the northern guinea and Sudan savanna in April (Late Dry Season) when the crude protein content of grasses are usually between 1.5 and $4.0 \%$. In Zamfara reserve, [7] reported a mean crude protein contents of herbage as 20.5, 12.2, 9.6 and 8.6\% for ERS, LRS, EDS and LDS respectively.

The net energy content of forage depends on the concentration of digestible energy in that forage. When forages of low digestibility are consumed by the animal, increased amount of energy are given off in the form of heat during the digestion process. Thus, a large proportion of the metabolize energy is wasted during eating and digestion of low quality forage as compared to forage of high digestibility. At 50\% digestibility, though, the forages are 50\% as efficient as grains in terms of energy provisions for maintenance and milk production, their efficiency is only $20 \%$ of grain for meat production [8]. As digestible energy is highly correlated with dry matter digestibility, energy requirements of ruminants are often expressed as total digestible nutrients (TDN) or starch equivalents (SE), and for tropical pastures these can be predicted from dry matter digestibility (DMD) and organic matter digestibility (OMD) data. At maturity the decline in net energy available to animals from forages will be more pronounced than the decline in digestibility, even though forage digestibility and net energy are related [8]. [7] reported a mean metabolized energy content of herbage at Zamfara reserve as $10.1 \mathrm{Mj} \mathrm{kg}^{+} \mathrm{DM}$.

\subsection{Description of the Study Area}

\section{Methodology}

The study was conducted at Giron Masa grazing reserve located 30km from Yauri town. It is situated in Shanga Local Government Area (LGA) South most tip of Kebbi State. The reserve lies between latitude $11^{\circ} 06^{1}, 483^{\prime \prime} \mathrm{N}$ and longitude $04^{\circ} 42^{1}, 356^{\prime \prime} \mathrm{E}$. The vegetation is that of typical northern guinea savanna, which consist of an almost continuous grass cover of not less than 1 meter in height. There are clumps of interspersed tree cover which averages 25-50 feet in height with a mixture of fine-leaved thorny trees and broad leaved deciduous species. The thick tree cover is found along streams and depressions [9]. The mean annual rainfall of the area is $1040 \mathrm{~mm}$. The rainy season last for 5-6 months, between April/May to October with heaviest amount in September, Temperature ranges from a minimum of $15-24^{\circ} \mathrm{C}$ in December/January to a maximum of $32-39^{\circ} \mathrm{C}$ in April/May. Relative humidity varies between $28-40 \%$ in the morning to $21-33 \%$ in the afternoon. The soil consist of well drained sandy loam soil and clay or clay loam soils on the fadama site. It is rich in organic matter especially the nomads settled spots [10].

\section{Method of Data Collection}

The study was conducted in July 2005- April, 2006 in four sub-seasons. The first collection was conducted in the early rainy season ERS (July), the second collection was done in the late rainy season LRS (October), the third collection was done in the early dry season EDS (January) and the fourth collection was conducted in the late dry season LDS (April).

Data were collected using three transects demarcated approximately 1kilometer apart. The herbage samples were collected by using $1.0 \mathrm{~m}^{2}$ wooden frame (quadrant). 12 sampling points were kept at an interval of 500 meters apart along each transect. At each point, the wooden frame was randomly thrown 5 times, thus making a total of 60 throws for each transect and a total of 180 throws for the three transects. In each point, percentage cover was determined by taking average percentage visual observation of three observers. Fresh weight of three most occurring species and remaining other species was taken by the use of spring balance for dry matter determination. In each point, a fresh representative sample of 200 and 100 grams were taken in the rainy and dry season respectively. The samples were labeled and air dried. Samples were analyzed for Crude Protein (CP), Crude Fiber (CF), Ether Extract (EE), Ash, Calcium (Ca) and Phosphorus (P).

\section{Statistical Analysis}

The data on percent plant cover DM yield and nutrient content were analyzed using SAS (1988) package. Mean were separated using Duncan Multiple Range Test (DMRT). 


\section{Results and Discussion \\ 4.1 Seasonal dry matter content of composite herbage at Giron Masa grazing reserve}

The mean percent dry matter (DM) content of herbage is presented in figure 2 .

From the figure, it can be observed that the mean percent dry matter content of herbage was significantly lower $(\mathrm{P}<0.05)$ in ERS and highest in LDS. There were however no significant differences $(\mathrm{P}>0.05)$ between dry matter content of herbage in EDS and LDS. From the figure, it could be observed that the mean dry matter yield of herbage was significantly lower $(\mathrm{P}<0.05)$ in ERS and highest in LRS. There was however no significant difference $(\mathrm{P}>0.05)$ between mean dry matter yield of LRS and EDS.

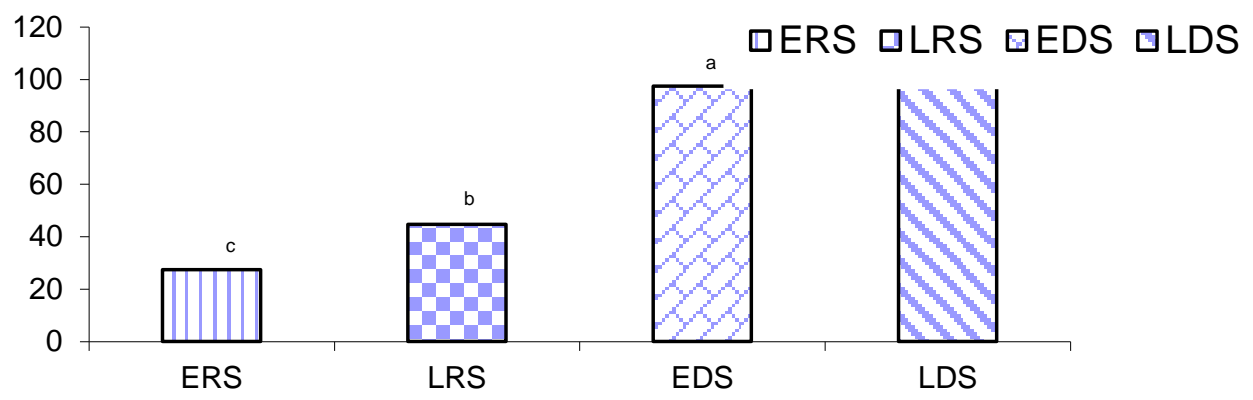

Figure 2: Mean seasonal DM content (\%) of herbage of Giron Masa grazing reserve

From the figure, it can be observed that the mean percent dry matter content of herbage was significantly lower $(\mathrm{P}<0.05)$ in ERS and highest in LDS. There were however no significant differences $(P>0.05)$ between dry matter content of herbage in Seasonal dry matter yield of herbage of Giron Masa grazing reserve

\subsection{Seasonal nutrient content of herbage at Giron Masa grazing reserve}

Results obtained for seasonal nutrient contents of herbage at Giron Masa grazing reserve are presented in Table 1. From the table, it could be observed that the crude protein (CP) content of herbage declined from ERS to LDS. The CP content was significantly higher $(\mathrm{P}<0.05)$ in ERS compared to other seasons. However, there were no significant differences $(\mathrm{P}>0.05)$ between the CP content of EDS and LDS.

Crude Fiber (CF) results indicated that LDS had the highest means (32.4\%). However, there was no significant difference ( $P>0.05$ ) between the CF content of ERS, LRS and EDS.

The results of the ash content obtained in this study indicated that early dry season had the highest mean value of $(19.5 \%)$. There was no significant difference $(P>0.05)$ between the ash content of ERS, LRS and EDS.

The ether extract (EE) content was highest (3.4\%) during the LRS and lowest (2.2\%) during the ERS. There was no significant difference $(\mathrm{P}>0.05)$ b twween the EE content of all the seasons.

Results of calcium $(\mathrm{Ca})$ content showed that ERS recorded the highest mean of $0.86 \%$. The results also indicated no significant difference ( $P>0.05)$ between Ca content of LRS, EDS and LDS.

Results of phosphorous (P) content showed that LDS recorded the highest mean of $0.53 \%$ and the same means of $0.44 \%$ was recorded in the remaining seasons. There was no significant difference $(\mathrm{P}>0.05)$ between the phosphorous content of ERS, LRS and EDS.

Table 1: Seasonal nutrient content of herbage of Giron Masa grazing reserve

\begin{tabular}{|c|c|c|c|c|c|}
\hline Nutrients & ERS & LRS & EDS & LDS & $\mathrm{SE}$ \\
\hline CP (\%) & $13.3^{\mathrm{a}}$ & $8.0^{b}$ & $6.2^{\mathrm{c}}$ & $5.6^{\mathrm{c}}$ & 0.36 \\
\hline $\mathrm{ASH}(\%)$ & $13.4^{\mathrm{b}}$ & $12.2^{b}$ & $11.8^{b}$ & $19.5^{\mathrm{a}}$ & 1.20 \\
\hline $\mathrm{Ca} \%$ & $0.86^{\mathrm{a}}$ & $0.65^{b}$ & $0.62^{b}$ & $0.58^{b}$ & 0.65 \\
\hline P \% & $0.44^{b}$ & $0.44^{b}$ & $0.44^{b}$ & $0.53^{\mathrm{a}}$ & 0.15 \\
\hline
\end{tabular}

$\mathrm{a}, \mathrm{b}, \mathrm{c}$ means in the same row with the same letter superscript are not significantly different $(\mathrm{P}>0.05)$

\subsection{Seasonal dry matter content \% of herbage of Giron masa grazing reserve}

Results obtained from present study indicated that the dry matter content increases with advancing herbage maturity over seasons. This result is in conformity with the report of [3] who reported that, younger 
forage tend to have low dry matter with high nutritive value while advancing maturity result in increase in dry matter with decreasing nutritive value.

The mean percent DM content of Giron masa reserve at ERS and LRS (27.54 and 44.68\%) is close to the values of 28.38 and $32.42 \%$ reported by [14] at Dabagi farm in July and August for virgin and fallow lands.

\subsection{Seasonal dry matter yield of herbage at Giron Masa grazing reserve}

Results obtained from present study have indicated a significant difference in the production of herbaceous plant mass of the reserve with other locations. The mean values obtained were higher than those reported by [11] and [7] for Zamfara Reserve, [12] for the semi-arid northeast Nigeria, and [13] for the semiarid Niger Republic. The results of the present study are also in agreement with the earlier report of [11], who observed that the highest herbaceous plant mass was attained at the peak of the rainy season. In this study, the highest standing mass was recorded in the month of October (LRS).

\subsection{Seasonal nutrient content of herbage of Giron Masa grazing reserve}

The CP contents reported in this study are lower than those reported by [7] who reported a mean CP content of 20.5, 12.2, 9.6 and 8.6\% for ERS, LRS, EDS and LDS respectively at Zamfara reserve. This could be due to higher herbage biomass obtained in the present studies compared to that of Zamfara as confirmed by [4] who reported that the nutritive value of the natural vegetation is generally higher at low biomass production levels as compared to high production levels. [4] reported a CP content of 10-20\% in EDS for the herbaceous sahelian pasture, which is higher than that obtained in the present study for EDS (6.2\%).

[3] reported that in many parts of the tropics under natural fertility condition and up to 2 months growth after the onset of rains, $\mathrm{CP}$ content in forages is well above 7\%. With uninterrupted growth due to high heat intensity, the grasses rapidly become mature and CP content drops drastically reaching value of $4-6 \%$ after 3 to 5 months. During the dry months CP content often drops below $4 \%$ and in later part of the dry season, values of 1-2\% have been recorded, [3]. These values are however lower than values obtained in the present studies in all the seasons. These variations in CP contents could be due to differences in species, level of soil fertility maturity stage of herbage and prevailing climatic condition, [1] and [11].

The CF values obtained in this study is close to (29.95\%) reported by [13] obtained from Cynodon dactylon cut at maturity. However, the values obtained are below 59.87\% CF reported by [14] obtained from wild sun flower plants. This variation could be due to species diversity and differences in stage of growth, [1] and [11].

The mean value of $13.4 \%$ recorded in this study was similar to the mean ash value of $13.5 \%$ reported for sun flower by [14] Similarly, all the values for all the seasons were above 9\% reported by [13]. Except in LDS the mean forage ash contents obtained in this studies are below the mean values reported by [7] who reported 17.7, 14.6, 14.8 and 19.4\% during the ERS, LRS, EDS and LDS respectively. However, similar value (19.5\%) was obtained during the LDS. The variations could be due to species diversity and stage of herbage growth, [1] and [11].

Results obtained for EE indicated that, the values were below the mean of $5.02 \%$ reported by [13] for Cynodon dactylon in a derived savanna zone of Nigeria. This could be due to differences in species, level of soil fertility, maturity stage of herbage and prevailing climatic condition, [1] and [11].

The results on Ca contents showed a decrease with increasing maturity over time. The trend was also the same as reported by [14]. The mean forages Ca content of $0.30+0.014$ and $0.29+0.023 \%$ for rainy and dry seasons respectively in the reserves of Kebbi state. Similarly, this study recorded higher values compared to that [14] at all the seasons.

Results on P content indicated that, except during the dry season, the values obtained in this study were similar but higher than those reported by [14] who reported mean forage phosphorous content of $0.120 \pm$ $0.003 \%$ and $0.047 \pm 0.025 \%$ for rainy and dry season in Kebbi State. The variation in Ca and P content could be due to differences in species, level of soil fertility, maturity stage of herbage and prevailing climatic condition, [1] and [11].

\section{Conclusion}

Results of the study indicated that except for crude protein, the levels of most nutrients reported in the present study are higher than those reported in the literature. Crude protein contents reported by [7] in all the seasons are higher than those reported in the present study. As it has been discussed earlier, the higher composition and physiological nature of Brachiaria lata of the herbaceous layer might affect the CP content of the samples analyzed. It could also be due to the level of soil fertility and prevailing climatic condition, [1] and [11].

Results obtained in the present study have therefore showed a significant effect of season on nutrient content of range herbage. Similar observations have been reported by [17]. Drop in feed quality in semi-arid 
areas has been attributed to drying of annual grasses and herbs and the shedding of leaves and seeds at the end of the rainy season as earlier observed. The decline in CP content from early rainy season to late dry season observed in the present study has also been reported by Rath [12] for Zamfara reserve. Despite all these effects, the nutrient contents of the herbage from Giron Masa grazing reserve are within the range considered normal for semi-arid environment. The significant seasonal effect on the quality of the feeds could also be considered normal for plants growing in the semi-arid environment. The dry matter yield data, herbaceous and ligneous species composition and nutrient quality obtained in the present study could be considered fair. This could hold optimum number of livestock with their nutritional requirements, especially during the growing season.

\section{References}

[1] Muller-Hohenstein, K. (1993). Auf dem Weg Zu einem neuen Verstandnis von Desertifikation - Uberlegungen aus der sichteiner .

[2] Ikhimioya I. and Olagunju B. O. (1996) Chemical Composition of Selected Green Plants available to small ruminants in the dry season in humid Nigeria. Tropicultural 14:115-117.

[3] Crowder, L. V. and H. R. Chheda (1982). Tropical Grassland Husbandry, Longman London Pp. 562. Hoffmann, I., C. WillekeWetstein and C. Schafer (1998). Description of grazing eco-system in north western Nigeria using environmental indicators. Animal Research and Development, Vol. 48, Institute for Scientific Co-operation, Tubingen Federal Republic of Germany. Pp. 6983.

[4] Breman, H., A. M. Cisse, M. A. Djiteye and W. T. Elberse (1979). Pasture dynamic and forage availability in the sahel. Israel Journal of Botany, 28: 227-251.Breman, H. and C. T. de Wit (1983). Rangeland productivity and exploitation in the Sahel, Science, 221:1341-1347.

[5] Le Houerou, H. N. (1980). Composition Chemique et valeur nutritive des fourrages Ligneux en Afrique Tropicale Occidentale In: Le Houerou, H. N. (ed). Les fourrages, Ligneux en Afrique - et al actuel des connaissances. ILCA Addis Ababa, Ethiopia. Pp. 259284.

[6] Agishi, E. C. (1983), Mineral Contents of Browse Plants, NAPRI Annual Report (1983), In: Adu, I. F. (ed) National Conference on Small Ruminant Production in Nigeria, NAPRI, Zaria, 1985.Agishi, E. C. (1985), Forage Resources of Nigerian Range Lands: In: Adu, I. F. (ed) National Conference, on Small Ruminant Production in Nigeria, NAPRI, Zaria, 6-10 ${ }^{\text {th }}$ October, 1985.

[7] Malami, B. S. (2005. Balancing nutrient supply and requirement of ruminants in Zamfara reserve North Western Nigeria. A Ph.D. Thesis, Department of Animals Science, Usmanu Danfodiyo University, Sokoto, Nigeria.

[8] Bula, T. J., V. L. Lechtenberg and D. A. Holt (1977), Potential of Temperature Zone Cultivated Forages: In Potential of the World's Forages for Ruminant Animal Production, Winrock and Int' Livestock Resource. Trg Cent. Arkansas, Pp.7-28.

[9] Udu, R. K. (1991). Geographical Regions of Nigeria Longman Ltd. Pp. 21-27.

[10] Yauri Metereological Station (2012). National Meteorological Agency, Kebbi State.

[11] Hiernaux, P. H. U. and M. D. Turner (1996). The effect of clipping on growth and nutrient uptake of Sahelian Annual Rangelands. Journal of Applied Ecology, 33: 387-399.

[12] Mortimore, M. (2000). Hard question for Pastoral Developments: a Northern Nigeria Perspective. Workshop on Pastoral Management, Niamey 2-6 October, 2000. Pierre Hiernaux and Eric Tielkes (eds). Praxisorientiertin Geobotanik, Phytoecologia, 23: 499-518.

[13] Aderinola, O. A., Farinu, G. O. Akinlade, J. A., Ojebiyi, O. O. Ige, A. O. and Adeyi, O. (2006). Effect of forms (fresh and dried) of feeding cynodon dactylon on feed intake, Digestibility and nitrogen balance in West African Dwarf Goats in a derived Savanna zone of Nigeria. In: I. R. Muhammad, B. F. Muhammada, F. Bibi - Farouk, Y. Shehu (ed) Proc of the $31^{\text {st }}$ Ann. Conf. Nig. Soc. for Animal Production BUK 12-15 March, 2006.

[14] Malami B. S. (1994). Survey and Quality Evaluation of some Grazing Reserves in Sokoto and Kebbi State of Nigeria. M. Sc. Thesis, Department of Animal Science, University of Nigeria Nsukka, Nigeria. 193pp.

[15] Akinlade, J. A., Farinu, G. O., A. A. Odunsi, A. Akingbade, F. G. Sodeinde, M. O. Ayansola and O. O. Ojebiyi (2006). Forage

[16] Penning de vries, F. W. T. and M. A. Djieye (1982). La productivite des paturages sahilians une'etude des sols des vegetations et de L'exploilation de cette resource naturelle, Pudoc, Wageningen, the Netherlands P. 525. 